\title{
FUNDAMENTAL IDEAS OF INFORMATICS AND THEIR RELATIONSHIP TO DIDACTICS OF INFORMATICS
}

\section{Ingrid NAGYOVÁ}

\begin{abstract}
The teacher of informatics should have a clear idea of the content of informatics, about the subject and the methods of its working and about the forms of its impacts in the world. In mathematics, biology and other courses, the subjects and methods of work are proven for centuries. Main subject of exploration of informatics is only gradually being born and only gentle crystallizes in development.

The impulse for writing this article was the results of the survey from practice for students of information technologies and informatics. They confirm the trend of recent years, when the informatics is perceived in the society as a technical discipline. This article analyzes the various aspects of informatics and tries to formulate the main subject of exploration of this field of human activity. Finding this subject is important for didactics of informatics, because it influences fundamentally the goals and methods of its teaching. Article also presents suggestions for practical guidance to teaching students - future teachers, with the aim give them insight into the theoretical basis of informatics and the boundaries of its exploration and impacts.
\end{abstract}

Key words: informatics, education informatics, fundamental ideas of informatics.

\section{ZÁKLADNÍ MYŠLENKY INFORMATIKY A JEJICH VZTAH K DIDAKTICE INFORMATIKY}

Resumé: Učitel informatiky by měl mít jasnou představu o obsahu informatiky, o předmětu a metodách její práce, o formách jejího působení ve světě. $\mathrm{V}$ matematice, biologii a dalších předmětech jsou předmět a metody práce staletími ověřené. Hlavní předmět zkoumání informatiky se postupně rodí a ve vývoji jen postupně krystalizuje.

Podnětem k sepsání příspěvku byla anketa mezi studenty informačních technologií a informatiky z praxe, která potvrzuje trend posledních let, kdy je informatika ve společnosti vnímána hlavně jako technická disciplína. Př́spěvek analyzuje jednotlivé aspekty informatiky a pokouší se formulovat hlavní předmět zkoumání tohoto oboru lidské činnosti. Jeho nalezení je pro didaktiku informatiky důležité, protože zásadně ovlivňuje cíle a metody její výuky. Příspěvek přináší také náměty na praktické vedení výuky studentů, budoucích učitelů, s cílem přiblížit jim teoretický základ informatiky a hranice jejího zkoumání a působení.

Klíčová slova: informatika, didaktika informatiky, základní myšlenky informatiky.

\section{1 Úvod}

Dějiny informatiky sahají daleko do minulosti a jsou spojeny s prvními úvahami nad obecnými algoritmy pro práci s čísly a jinými údaji. Pojem, z něhož vychází dnešní slovo algoritmus, se objevuje již ve středověku, $\mathrm{v}$ osmém století v Persii. Princip algoritmizace byl znám již dříve. Myšlenky sestrojit programovatelný stroj, který by dokázal sám provádět jisté výpočty, se objevuji na konci 18 . století. Začátkem následujícího století jsou první takové stroje doopravdy sestaveny.

$\mathrm{Z}$ tohoto pohledu rozhodně nemůžeme nahlížet na informatiku jako na mladý obor. Definice a konstrukce algoritmů a na jejich základě konstrukce automatických strojů zajímaly lidi již v dávné době. Přesto víme, že $\mathrm{v}$ této době byla informatika jenom $\mathrm{v}$ počátcích, jenom velice nesměle si razila cestu na svět. Ještě dlouho neexistovaly osobní počítače, neexistoval internet, či interaktivní tabule. Ty stoje, které se postupně dařilo konstruovat, byly sice na svou dobu fantastické, přesto je dnes najdeme leda $\mathrm{v}$ počítačových muzeích.

V dnešní době často slýcháme, že se informatika vyvíjí velice rychle. Tento názor je zcela opodstatněný při pohledu na rychlý vývoj v oblasti počítačové techniky, ohromnou evoluci v oblasti počítačů (notebooky, tablety, chytré telefony apod.), vyvíjení větších pamětí, dokonalejších obrazovek, nových verzí programů apod. Na druhou stranu odborníci $\mathrm{v}$ oblasti 
informatiky si uvědomují, že vývoj informatiky (zejména jejího základu, jejich základních myšlenek) není až tak překotný, jak se z pohledu vývoje techniky může zdát. Uvědomují si, že mnoho základních myšlenek, na nichž je informatika postavena, jsou myšlenky z ,informatických“ počátků a zůstávají od té doby prakticky neměnné.

Při zamýšlení se nad definicí informatiky jako vědy je potřeba zohlednit mnoho aspektů:

- Pojem informatika souvisí s informacemi a informatika se informacemi zabývá. Studuje možnosti získávání, ukládání, uchovávání a zpracovávání informací.

- Informatika je často spojována s počítačem. Počítač ale není hlavním předmětem zkoumání informatiky.

- V anglicky mluvícím světě se setkáváme s výrazem „počítačová věda“ (computer science) nebo $\mathrm{V}$ poslední době také s označením „výpočetní věda“ (computing science). Takto je často informatika vnímána jako věda o počítačích, jako věda, pro niž je počítač hlavním předmětem zkoumání. Tento pohled na informatiku je nutno jasně oddělit - počítač jako nástroj byl již historicky až druhotným předmětem zkoumání informatiky. Základní myšlenky informatiky se formovaly již v osmém století, kdy se setkáváme s prvními algoritmy.

- Hlavními pojmy informatiky jsou: informace a zpracování informací, algoritmus, program, jazyk apod.

- Charakterizovat informatiku jako vědu je velice obtížné. Věda by měla mít vlastní metody pro výzkumnou práci. Informatika tyto metody $\mathrm{v}$ mnoha směrech zatím pouze hledá, vědecká práce $\mathrm{v}$ oblasti informatiky se soustřed'uje nejvíc do technických oblastí (mnohé technické novinky a inovace). Myšlenky informatiky se vyvíjí a mění mnohem pomaleji.

- Informatika byla v minulosti pěstována jako speciální odvětví jiných vědeckých disciplin (logiky, matematiky, elektrotechniky apod.). Postupně se však vyvíjí v samostatný obor lidské činnosti, který zpětně v mnoha oblastech působí na ostatní obory a vědecké oblasti.

$\mathrm{Na}$ základě vyjmenovaných aspektů lze informatiku definovat jako obor lidské činnosti, který se zabývá zpracováním informací.
Zpracování informací může sestávat z množství jednotlivých činností a procesů, na informatiku proto můžeme nahlížet více způsoby - z pohledu hardwaru a softwaru, z pohledu počítače jako technického prostředku, ale také jako na teoretický obor zabývající se formálními modely práce s informacemi a jejich chováním.

Pro výuku je způsob náhledu na informatiku důležitý. Ovlivňuje obsah výuky a charakter předávaných informací, použité metody a postupy a $\mathrm{V}$ neposlední řadě přístup učitele. Pokud budeme na informatiku nahlížet jako na technické odvětví zabývající se zejména hardwarem, pak výuka informatiky bude výukou technického oboru, výukou o strojích a zařízeních, o výrobních procesech apod. Naopak výuka teoretické informatiky, výuka formálních jazyků a automatı̊ bude velice blízká výuce matematiky a uplatní její didaktické a pedagogické metody.

Společenský pohled na informatiku a její vnímání a uchopování učiteli, ale také studenty informatických učitelských oborů významně ovlivňuje metody a postupy práce $\mathrm{v}$ hodinách informatiky. Analýza názorů studentů studijního oboru Informační technologie ve vzdělávání je jedním z možných způsobů jak nahlédnout na názory jisté části společnosti na obsah informatiky. Navíc se taková analýza může stát východiskem pro přemýšlení a znovuzařazení mnoha opomíjených témat $\mathrm{v}$ prípravě studentů informatických učitelských oborů.

\section{Základní pojmy informatiky}

Jednotlivé aspekty informatiky, jak jsou uvedeny v úvodu, naznačují, které z pojmů a myšlenek tvoří její základ. Naznačují jaké metody a postupy práce $\mathrm{s}$ informacemi informatika používá. Schubert a Schwill [4] označují za základní myšlenky informatiky pojmy algoritmus, strukturální rozklad a jazyk. Tyto tř̆i myšlenky tvoří základ, který při hlubších analýzách může být zdrojem dalších myšlenek.

Je samozrejmostí, že algoritmizaci pojímáme jako základní myšlenku informatiky. Lze ji uplatnit ve všech fázích životního cyklu softwaru, podle čehož rozlišujeme čtyři velké oblasti, v nichž algoritmizace nachází nezastupitelné místo:

- Při návrhu algoritmu použiváme návrhová paradigmata, jako jsou strukturované nebo objektově orientované programování, 
metody „shoda-dolů“, „rozděl a panuj“, „prohledávání s návratem“ apod.

- Návrh je následně převeden do programu. K tomu jsou k dispozici určité společné koncepty, jako například zřetězení, alternativa, rekurze atd.

- Hotový program je realizován na jednom (nebo více) procesorech. S tím souvisí myšlenka procesu.

- Poslední skupina myšlenek v rámci algoritmizace se zabývá hodnocením algoritmů zhlediska kvality. Hlavními kritérii hodnocení jsou správnost, úplnost a časová nebo prostorová náročnost.

Myšlenka jazyka hraje významnou roli nejen při programování (programovací jazyky), při specifikaci (specifikační jazyky), při ověřování (logické úvahy a výrazy), v databázích (dotazovací jazyky), či v operačních systémech (př́kazové jazyky). Jistou formou jazyka jsou i grafy nebo tabulky, myšlenkové mapy apod.

$\mathrm{V}$ úzkém vztahu $\mathrm{k}$ jazykům stojí myšlenky syntaxe a sémantiky, myšlenky překladu nebo interpretace daného jazyka.

Ve strukturálním rozkladu můžeme jasně rozlišit dva základní aspekty:

- Vertikální aspekt, tzv. hierarchizace, jež popisuje rozložení předmětu na úrovních různých stupňů abstrakce. Systém se člení na konečný počet hierarchických úrovní s různým stupněm abstrakce. Myšlenku hierarchizace najdeme např́klad v modelech úrovní architektury počítače, v jazykových hierarchiích, strojových modelech, ISO-OSI úrovňovém modelu apod.

- Horizontální aspekt, tzv. modularizace, popisuje rozložení předmětu na jednotlivé díly stejné úrovně abstrakce. Každý systém se dá vysvětlit pomocí vlastností jeho částí, dá se chápat jako suma jeho na sobě zcela nezávislých dílů (odspoda nahoru), resp. se dá rozložit na zcela nezávislé díly (shora dolů).

Hierarchická modularizace vzniká smíšením obou základních forem.

\section{Projevy informatiky v reálném světě}

Základní myšlenky informatiky, metody a principech její práce lze demonstrovat na mnoha praktických př́kladech. Právě příklady z praxe jednoznačně vymezí hranice, kde se v reálném světě projevují prístupy informatiky.

\section{Př́iklad 1: Přesun chrámu v Abu Simbel}

Začněme jednou příhodou $\mathrm{z}$ minulosti. Při stavbě Asuánské přehrady bylo rozhodnuto, že chrám v Abu Simbel budou pro jejich zachování přesunuty na nové místo. V letech 1964 - 1968 se začalo $\mathrm{s}$ rozkládáním celého chrámu na jednotlivé kamenné kvádry o průměrné váze 20 tun. Velké kusy, jako například sochy faraona z velkého chrámu, musely být opatrně rožrezány na menší kusy, aby byl možný jejich přesun. V̌̌echny odvážené kameny byly pečlivě katalogizovány a následně znovu poskládány na novém místě asi 200 metrů od původního stanoviště. Velké sochy se vyztužily ocelovými tyčemi a poskládaly znovu dohromady se snahou, aby nebyly vidět provedené řezy. [6]

Podívejme se podrobně, jak tento gigantický projekt probíhal. Sochy byly rozrezány na kvádry. Jako první byly řezány bloky z horních částí chrámu, jako poslední bloky z jeho dolních partií. Kvádry byly nakládány na auta, která postupně vezla jednotlivé bloky nahoru do kopce. Auta tak vyvážela nejprve horní části chrámu a následně pak spodní části. Je zřejmé, že s opětovnou výstavbou chrámu se mohlo začít až po převezení všech bloků do kopce. Na kopci tak vzniklo úložiště kvádrů.

Příběh přesunu chrámu Abu Simbel má pouze historickou hodnotu. Protože se jedná o řešení problémů, informatika zde nachází také své místo [3]. Auta převážející kvádry se řadí do fronty za sebe. Úložiště kvádrů funguje jako zásobník kvádry, dovezené nakonec, budou při opětovné výstavbě chrámu použity jako první. Tak se zde při řešení reálného praktického př́kladu setkáváme s datovými strukturami informatiky, $\mathrm{s}$ frontou aut a seznamem či zásobníkem kvádrů.

\section{Příklad 2: Hanojské věže}

Problém hanojských věží je obecně znám. Máme tři tyče a x kotoučů seřazených na sobě od největšího po nejmenší. Podle daných pravidel je potřeba přesunout kotouče na koncovou tyč.

Je zřejmé, že tento problém není problémem informatiky, lze ho řešit bez jakýchkoliv znalostí této vědy. Informatiku v něm můžeme objevit, pokud napríklad budeme postupně zaznamenávat velikost aktuálně přesouvaného kotouče - viz obrázek 1 pro šest kotoučů.

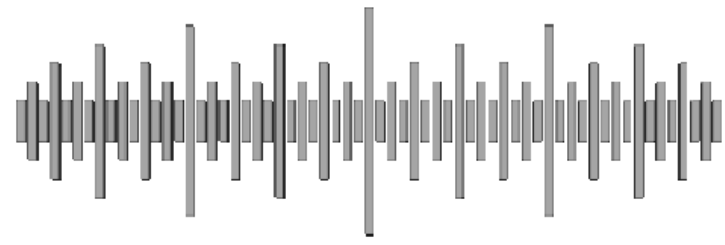


Obr. 1: Přesun šesti kotoučũ.

Z obrázku lze zjistit, že největší kotouč je přesouván přesně uprostřed celého procesu a že celý proces je podle tohoto kotouče „symetrický“, tj. levá i pravá polovina obrázku jsou identické. Na ně lze rekurzivně aplikovat stejné pravidlo, tj. pátý kotouč je přesouván přesně uprostřed levé poloviny obrázku, ale také uprostřed pravé poloviny apod. Tato analýza přesunu kotoučů a objev rekurze nás opět přivádí $\mathrm{z}$ reálného světa do oblasti informatiky.

Jiný pohled na přesun kotoučů nabízí pohled inspirovaný nadreálnými čísly. [2] Posloupnost dvojkových čísel (počet cifer čísla odpovídá počtu kotoučů) tak, že na první nulové číslo posloupnosti aplikujeme pravidlo změny nuly na jedničku nebo opačně při přesunu kotouče $v$ řádu čísla odpovídajícímu velikosti tohoto kotouče.

Pro tři kotouče dostáváme např́klad posloupnost osmi dvojkových čísel:

$$
\text { 000, 001, 011, 010, 110, 111, 101, } 100
$$

Pro čtyři kotouče dostaneme posloupnost šestnácti dvojkových čísel:

0000, 0001, 0011, 0010, 0110, 0111, 0101, 0100, 1100, 1101, 1111, 1110, 1010, 1011, 1001, 1000.

První polovina této posloupnosti je (až na první nulu v každém čísle) shodná s posloupností pro tři kotouče. Pak se ale vše obrací a druhá polovina posloupnosti je (až na první jedničku) vzhledem k posloupnosti pro tři kotouče převrácena (otočena). $\mathrm{V}$ těchto částečně matematických zákonitostech se projevují a ukazují zákonitosti rekurze v informatice.

\section{Použité výzkumné metody}

Názory studentů informatických oborů na informatiku mohou ovlivnit směr jejich vzdělávání, a to zejména zařazení opomíjených témat, či způsoby seznámení s principy práce informatiky. Analýza názorů studentů studijního oboru Informační technologie ve vzdělávání se stala východiskem pro tuto práci. Obor Informační technologie ve vzdělávání je vyučován na Pedagogické fakultě Ostravské univerzity v Ostravě v prezenční i kombinované formě. Studenti se mohou vzdělávat v bakalářském stupni nebo v navazujícím magisterském studiu.

I přesto, že se jedná o neučitelský obor, absolvují studenti tohoto oboru již v bakalářském stupni teoretickou pedagogickou př́pravu, včetně př́pravy $\mathrm{v}$ oblasti didaktiky informatiky.
Studenti zahajující svá studia v tomto oboru bývají zaskočení skladbou informatických předmětů a jejich sylabem. To často vede $\mathrm{k}$ ztrátě zájmu o studovaný obor, nebo až k ukončení studia. Zejména první hodiny algoritmizace a programování, matematiky či logiky se pro mnoho studentů stává posledními hodinami na vysoké škole. To nás neustále vede $\mathrm{k}$ zamyšlení se nad důvody tohoto stavu: Co si studenti přicházející na školu studovat informatický obor pod pojmem informatika představují? Co od svého studia očekávají? Lze algoritmické myšlení chápat jako základ informatiky i v dnešní době, nebo je to pouhý přžitek a informatika má $\mathrm{v}$ dnešní době jiné poslání? $\mathrm{V}$ tom případě jaké?

Hledání odpovědí na tyto otázky je velice problematické. Studenti, kteří mají na počátku studia problémy, se obvykle velice rychle ztratí ze studia. Získat jejich zpětnou vazbu je proto velice komplikované. K zjištění názorů studentů prvních ročníků využiváme proto hlavně metodu rozhovoru.

Při hledání odpovědí na položené otázky jsme se zaměřili naopak na studenty končící své studiu, tj. na studenty tretího ročníku bakalářského stupně. Tito studenti prošli velkou část vysokoškolského vzdělávání na pedagogické fakultě v oblasti informačních technologií a jejich názory na informatiku by měly být již zformovány. Absolvovaly technicky zaměřené předměty zabývající se počítačovými sítěmi a periferiemi počítačů, předměty zaměřené na praktickou multimediální tvorbu, ale také predměty zaměřené teoreticky, jako algoritmizace a programování, databázové a informační systémy apod.

Hlavním smyslem provedené analýzy bylo zjistit názory studentů třetího ročníku bakalářského studia na informatiku a na předmět jejího zkoumání. Názory studentů byly zjišt'ovány $\mathrm{v}$ předmětu Didaktika vzdělávacích technologií. Použitou metodou byla metoda dotazníku s otevřenou otázkou vyžadující krátkou tvořenou odpověd' ve vymezeném rozsahu. Dotazník byl distribuován formou korespondenčních úkolů v kurzu.

Sběr dat probíhal ve dvou etapách - před započetím výuky a po jejím ukončení. Zadání prvního korespondenčního úkolu znělo:

,Zamyslete se nad pojmem informatika. Vypište 20 pojmü, které tento obor podle Vás charakterizuji. Pojmy seřad'te do kategorii nebo 
podle důležitosti. Můžete je seřadit do myšlenkové mapy. "

Z výsledků analýzy (viz dále) vyplynulo, že je nezbytné studentům vysvětlit mnohé z principů a metod práce informatiky. Vhodným nástrojem se ukázaly být př́klady z praxe (viz kapitola 3), na nichž bylo možné demonstrovat hranici mezi tím, co informatika ještě není a kdy reálný problém může být řešen metodami informatiky,

Po objasnění principů a metod zkoumání informatiky na příkladech bylo zadání původního korespondenčního úkolu doplněno o text:

„,Tento seznam bude obsahovat pojmy, které prímo nesouvisí $s$ počitačem a nejsou pojmenováním částí počitače. Hledejte, prosím, co to je informatika, co se doopravdy za tímto pojmem skrývá."

V obou př́padech byly odpovědi studentů shromážděny a podrobeny pečlivé evaluaci, a to jak gramatické (odstranění překlepů, drobných chyb, jednotné skloňování), tak obsahové vyhledání synonym (software a program apod.).

Odpovědi byly poté seřazeny podle abecedy a seskupeny do skupin. Ve výsledcích byly důležité zejména četnosti výskytů jednotlivých odpovědí studentů.

\section{Průběh a výsledky analýzy}

$\mathrm{Z}$ pravidelných rozhovorů se studenty prvního ročníku oboru Informační technologie ve vzdělávání vyplývá, že algoritmické myšlení a programátorské dovednosti rozhodně nepovažují za základ informatického vzdělávání, a pokud ano, nepočítají s tím, že by se těmto předmětům měli věnovat na pedagogické fakultě nebo dokonce jako budoucí učitelé celoživotně. Jejich chápání informatiky je značně zkresleno výukou dovedností práce s kancelářskými balíky, kterou absolvovali na střední škole, a také používáním internetu, jeho sociálním postavením, počítačovými hrami apod. Někteří ze studentů spojují informatiku alespoň s nutnými technickými prostředky a potřebou základních znalostí o jejich funkčnosti a využitelnosti. Algoritmický prrístup k řešení problémů rozhodně nevnímají jako nutnou součást jednotlivých činností a procesů informatiky.

U studentů třetích ročníků jsme provedli dotazníkové šetření popisované výše. První dotazník (korespondenční úkol) řešili studenti v hodině bez předchozích instrukcí a diskuze. Průzkumu se zúčastnilo 23 studentů, 18 studentů prezenčního studia a 5 studentů kombinovaného studia.

Rozborem a následnou validací pojmů jsme získaly 350 pojmů od studentů prezenční formy studia a 108 pojmů od kombinovaných studentů.

Nejčastěji uváděným pojmem je pojem program, resp. software (viz tabulka 1). To uvedlo 17 prezenčních studentů a všichni studenti kombinované formy. K tomu lze také prripočíst poměrně vysoký výskyt pojmu programování. $\mathrm{Z}$ toho lze usuzovat, že studenti třetího ročníku vnímají spojení informatiky s programy a programováním. Ve srovnání s výsledky studentů prvních ročníků lze konstatovat, že tento názor je důsledkem absolvované výuky na vysoké škole a to je jistě pozitivní zjištění.

\begin{tabular}{|l|c|c|}
\hline Pojem & $\begin{array}{c}\text { Prezenční } \\
\text { forma }\end{array}$ & $\begin{array}{c}\text { Kombinovaná } \\
\text { forma }\end{array}$ \\
\hline $\begin{array}{l}\text { Program, } \\
\text { software }\end{array}$ & $17(94 \%)$ & $5(100 \%)$ \\
\hline Počítač & $14(78 \%)$ & $3(60 \%)$ \\
\hline $\begin{array}{l}\text { Zpracování } \\
\text { informací }\end{array}$ & $13(72 \%)$ & $3(60 \%)$ \\
\hline Hardware & $11(61 \%)$ & $3(60 \%)$ \\
\hline Internet & $11(61 \%)$ & $2(40 \%)$ \\
\hline Programování & $11(61 \%)$ & $2(40 \%)$ \\
\hline Myš & $9(50 \%)$ & $2(40 \%)$ \\
\hline
\end{tabular}

Tab. 1: Nejčastěji uváděné pojmy.

Dalšími často uváděnými pojmy jsou pojmy počitač a zpracováni informací. Nejčastěji uváděné pojmy tak $\mathrm{z}$ velké části pokrývají základní aspekty a myšlenky informatiky, jak byly vyjmenovány $\mathrm{v}$ úvodu. Pojem algoritmus uvedla do souvislosti s informatikou pouze trretina studentů.

Překvapivé je zjištění, že polovina studentů si spojuje informatiku s pojmem myš (počítačová myš). V seznamu pojmů se objevilo také více různých pojmenování dalších periferií počítače či konkrétních softwarových produkti̊. Proto byly pojmy seřazeny do speciálních skupin:

- Pojmy označující periferie a další technická zařízení připojitelná $\mathrm{k}$ počítači, například myš, klávesnice, monitor, reproduktory, tiskárna apod. Skupina nese označení TECH.

- Pojmy označující jména konkrétních softwarových produktů, například Excel, Word, Delphi apod. Skupina je označena $P R G$.

Skupiny TECH a $P R G$ poukazují na kontroverzní názory a slovní spojení. Jistě by 
byla možná analýza dalších skupin pojmů, ta by však pouze potvrzovala předchozí.

Tabulka 2 sumarizuje výsledky vobou skupinách. Z tabulky je zřejmé, že technická zařízení (skupina TECH) se mezi pojmy souvisejícími s informatikou vyskytují s frekvencí $20 \%$ u studentů prezenční formy studia a $15 \%$ studentů kombinované formy. Přitom je potřeba zdůraznit, že tiskárna, myš, klávesnice, monitor apod. nemají s informatikou mnoho společného. Z analýzy vyplývá, že studenti kombinované formy, kteří obvykle přichází z praxe, si tuto skutečnost uvědomují víc než studenti prezenční formy.

\begin{tabular}{|l|c|c|}
\hline Pojem & $\begin{array}{c}\text { Prezenční } \\
\text { forma }\end{array}$ & $\begin{array}{c}\text { Kombinovaná } \\
\text { forma }\end{array}$ \\
\hline$T E C H$ & $71(20 \%)$ & $16(15 \%)$ \\
\hline$P R G$ & $25(7 \%)$ & $0(0 \%)$ \\
\hline
\end{tabular}

Tab. 2: Četnost výskytů pojmù ve skupinách.

Významné je také procento vyjmenovávaných konkrétních jmen softwarových produktů. Tato skutečnost je zajímavá i $\mathrm{z}$ toho důvodu, že kombinovaní studenti takový produkt vůbec neuvedli. U studenti prezenční formy studia se mezi pojmy vyskytlo $7 \%$ pojmenování konkrétních programů. Tito studenti obvykle do studia nastupují ihned po skončení střední školy. Jsou často přesvědčeni, že vše záleží na použitých softwarových produktech, použitých tlačítkách a položkách nabídek programů. Většinou nedokážou znalosti zobecnit, nejsou schopni abstrakce (viz také [5]).

Druhé etapy dotazníkového šetření po absolvování výuky se zúčastnili pouze studenti prezenční formy studia, úkol odevzdalo 17 studentů.

Následná analýza pojmů se zde ukázala nemožnou. Studenti o problému začali přemýšlet a z jednoduchých pojmů se stala slovní spojení. Hlavním prínosem byla vyšší míra abstrakce a zobecnění v řešení úkolů. Část úkolu vybraného studenta a změnu $v$ jeho řešení znázorňuje obrázek 2 - část myšlenkové mapy před a po zamyšlení nad hranicemi informatiky. Student ve svém řešení nahradil jednotlivá technická zařízení spíše jejich modely nebo principy fungování. Tím také pozměnil oblast z technické na spíše teoretickou informatiku. Tento proces lze vysledovat $\mathrm{v}$ práci většiny studentů.
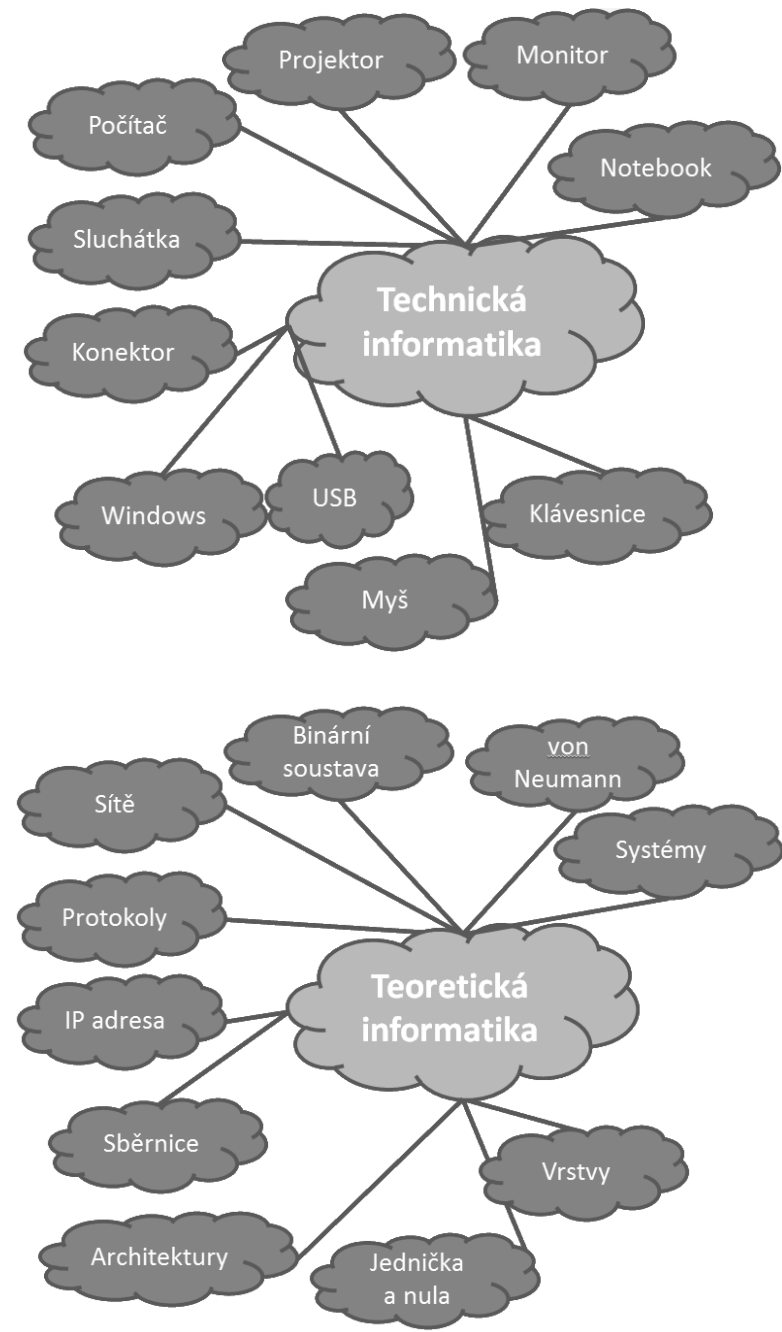

Obr. 2: Proměna korespondenčního úkolu.

\section{Diskuze a závěry}

Není daleko doba, kdy informatika a práce na počítači byly př́mo spojovány s algoritmizací a programováním, kdy všechny činnosti na počítači vyžadovaly programátorskou práci. Pokud člověk nebyl současně programátor, počítač nemohl a nedokázal využít.

Pojímání informatiky $\mathrm{v}$ dnešní době se radikálně změnilo. Počítače využíváme při celé řadě činnosti - pro psaní textových dokumentů, pro komunikaci, vyhledání a zpracování informací apod. K tomu nám složí programové vybavení počítače, jehož grafické uživatelské rozhraní je dnes na takové úrovni, že k jeho obsluze nepotřebujeme většinou žádné speciální znalosti či dokonce programátorské dovednosti.

A tak pomalu zapomínáme na původ jednotlivostí, jež umožnily vývoj počítačů a jejich možností. Pomalu opomíjíme důležitost algoritmického myšlení a představivosti, př̀ práci s počítačem si neuvědomujeme, že pracujeme se 
softwarem, který někdo vyvinul a který i přes maximální snahu autora o intuitivnost a jednoduchost ovládání, přesto od nás očekává a předpokládá algoritmický a logický přístup. Jednoduché opakující se činnosti se mohou stát rutinní práci s počítačem, ale vše nové vyžaduje použití jistých principů, které nutně vychází $\mathrm{Z}$ algoritmizace. Tato skutečnost se projevuje při hledání základních myšlenek informatiky (viz kapitola 2). Tento princip můžeme objevovat při řešení nejrůznějších problémů s využitím metod a principů informatiky (viz př́klady v kapitole 3 ).

Situace je komplikovanější ve výuce na školách, kde si algoritmický př́stup musí neustále hledat a obhajovat své místo. Žáci a studenti velice snadno sklouzávají k stereotypům a nabývají dojem, že programování není nutným předpokladem kvalitní práce s počítačem. Vysoká teoretická náročnost a abstraktnost algoritmizace je $v$ tomto přesvědčení jenom utvrzuje. Potvrzují to také názory prezentované studenty, budoucími učiteli informatiky (viz kapitola 5). Tlak na nepotřebnost a nevyužitelnost algoritmizace a programování a opomínání pravé podstaty informatiky nabývají takové sily a rozměrů, že myšlenka algoritmizace ztrácí ve výuce informatiky na významu.

Trend ,zapomínání na algoritmy“ bude jistě ve společnosti pokračovat. Jak již bylo naznačeno, tento trend by ale neměl ztrácet na významu v prrípravě učitelů informatiky. Navíc se právě algoritmický př́stup k řešení problémů může stát oživujícím prvkem výuky, at' již při projektové výuce, př̀ tvořivé hře v konstruktivisticky orientovaných prostredích (LOGO [1], SCRATCH, LEGO roboti apod.), či při jiných aktivitách. Uvedené praktické př́klady $\mathrm{v}$ kapitole 3 to jenom potvrzují.

Př́ispěvek navazuje na projekt Inovace doktorského studijního programu „ICT ve vzdělávání“ - CZ.1.07/2.2.00/18.0005.

\section{Literatura}

[1] BLAHO, A., KALAS, I. Imagine Logo Primary Workbook. Logotron, Cambridge

[2] KNUTH, D. E. Nadreálná čísla. Pokroky matematiky, fyziky a astronomie. Praha: Jednota českých matematiků a fyziků, 1978. Číslo 23 (1978).

[3] NAGYOVÁ, I. Lineární abstraktni datové typy. Sborník prríspěvků z konference a soutěže eLearning 2009. Hradec Králové: Gaudeamus, Univerzita Hradec Králové, 2009. s. 23-27. [2009-11-10]. ISBN 978-80-7041-971-7.

[4] SCHUBERT, S., SCHWILL, A. Didaktik der Informatik. Heidelberg: Spektrum, 2004. ISBN 38274-1382-6.

[5] VANÍČEK, J. Didaktika informatiky a výpočetní techniky. Studijní text pro studenty. České Budějovice: JČU, 2004.

[6] Wikipedie, otevřená encyklopedie. URL: <http://cs.wikipedia.org/>

RNDr. Ingrid Nagyová, PhD.

Katedra informačních a komunikačních

technologií

Pedagogická fakulta OU

Mlýnská 5

701 03, Ostrava, ČR

Tel: +420 597092630

E-mail: ingrid.nagyova@osu..cz

Www pracoviště: http://pdf.osu.cz/kik/ 